\title{
Pioneering Establishment of Teaching Factory Poultry Slaughterhouse at Politeknik Negeri Jember Based on SWOT Analysis
}

\author{
Hariadi Subagja ${ }^{1, *}$, Satria Budi Kusuma ${ }^{2}$, Shokhirul Imam ${ }^{3}$ \\ 1, 2, 3 Department of Animal Science, Politeknik Negeri Jember, Indonesia \\ *Corresponding author Email: hariadi_subagja@polije.ac.id
}

\begin{abstract}
The purpose of this research is to create a competitive strategy by conducting a SWOT analysis on the pioneering establishment of the Teaching Factory (Tefa) of the of the Jember State Polytechnic (Polije). The research was carried out in several locations which included activities in the field to obtain primary data. The research locations include traditional and modern markets in Jember, Poultry Slaughterhouse, chicken collectors, hotels, restaurants, catering, and chicken meat sellers around the city of Jember. Tools used to retrieve and process primary data include stationery, smartphones, and laptops. The material used for data collection is questionnaire paper. To obtain data that is accurate and reliable, and relevant to the problem under study, data collection is carried out by several methods, namely interviews, observations, questionnaires, and literature studies. SWOT analysis in this study was conducted by determining the combination of internal and external factors. SWOT analysis compares internal factors, namely strengths and weaknesses with external factors, namely opportunities and threats to formulate a competitive strategy for Polije poultry slaughterhouse. The results showed that the position of the Polije poultry slaughterhouse pilot was at coordinates 3.09 and 2.97. These coordinates are located in quadrant I, which means that it supports an aggressive strategy. The conclusion of the research is that the position of poultry slaughterhouse Polije is very strong and supports the strategy to improve and develop the resulting product.
\end{abstract}

Keywords: Teaching Factory, Poultry Slaughterhouse, SWOT Analysis

\section{INTRODUCTION}

Broiler chicken is a type of chicken that is maintained for meat use. The characteristics of this product can be accepted by all levels of Indonesian society because the priceis relatively cheaper than beef and goat/ lamb and easily obtained becauseit has spread throughout Indonesia [1].

Poultry Slaughterhouse is a building complex designed with special construction to meet certain technical and hygienic requirements to be used as a place to cut poultry (generally chicken) for consumption by the community [2]. Poultry Slaughterhouses are one of the downstream components of chicken farming business. Chicken slaughter is an effort to turnlive chicken into a product in the form of carcass that chickens that are ready to be processed [3]. The purpose of chicken meat slaughter is to meet the needs of chicken meat for the community. In the provision of chicken meat is generally done through Poultry Slaughterhouse, both coordinated and unood by the government. The provision of chicken meat must meet the requirements of safe and fit for consumption [4].

The Polije Farm Department has a complete poultry slaughterhouse building and facilities, has stunertools, chicken hanging, plucker, echoing table, tub chilling, washing tub, scalder, pot, and gas stove, plus 1 technician who has been certified meat slaughter expert (Butcher). However, so far it has only been used as a place for student practicum, even though poultry slaughterhouse facilities can be used as Teaching Factory, so that it can be better anddevelop. Tefa concept is a learning approach concept that combines a learning and working environment so as to achieve a real and relevant learning experience in accordance with existing industries [5][6][7].

From the above description, it is necessary to conduct studies related to the Establishment of a Poultry Slaughter House Teaching Factory at Politeknik Negeri 
Jember Based on SWOT Analysis, so as toestablish a competitive strategy towards the products produced.

\section{RESEARCH METHODS}

\subsection{Research Location}

Research is conducted in several locations that include activities in the field to obtain primary data. Research locations include Traditional Market (Tanjung Market, Kreongan Market, Kepatihan Market and Patrang Market) and modern market (Lippo Plaza, Transmart,Giant) in Jember, poultry slaughterhouse, Steamer, Hotel, Restaurant, Catering, and Chicken Butcher around Jember.

\subsection{Tools and Materials}

Tools used to retrieve and process primary data include stationery, smartphones, and laptops. The material used for data retrieval is questionnaire paper.

\subsection{Research Methods}

\subsubsection{Data collection methods}

To obtainaccurate and trustworthy truth and relevant to the problem studied, the collection of data is done by several methods, namely interviews, observations, questionnaires, and literature studies.

\subsubsection{SWOT analysis method}

The SWOT analysis in this study is done by determining a combination of internal and external factors. SWOT analysis compares internal factors, namely strength (stregth), and weakness. External factors are opportunities and threats. Internal factors are incorporated into matrics called IFAS factor matrix (Internal Strategic Factor Analysis Summary). External factors are incorporated into matrics called external factor matrix or EFAS (External Strategic Factor Analysis Summary). After the matric internal and external strategy factors are completed, the results are incorporated into a qualitative model, namely SWOT matrix to formulate a competitive strategy for Poultry Slaughterhouse.

\section{RESULTS AND DISCUSSIONS}

\subsection{Internal strategy factors and external strategies Matrix}

\subsubsection{Internal strategy factors Matrix}

Internal environment analysis depicts strength and weakness that owned by Tefa Polije. Internal environment analysis that depicts strength as follow:
1. Have a certified halal slaughterman

2. Equipment for Poultry Slaughterhouse operational needs that are sufficient enough

3. Has adequate facilities / standard minimal Poultry Slaughterhouse

4. The location of poultry slaughterhouse Polije is quite strategic (in the city area)

5. Poultry carcass products produced are guaranteed to meet the criteria of ASUH (Safe, Healthy, Whole, and Halal)

6. Large enough target market (minimum Polije employees)

7. Having a marketing partner is a Cooperative Of Polije Employees which is strategically located

8. Has a good name (reputation) Polije as one of the best polytechnics in Indonesia

While Internal environment analysis that depicts weakness as follow:

1. Production capacity has not been maximal and still needs to be increased.

2. There is no human resources (HR) and/or a dedicated professional team focused on managing the production of poultry slaughterhouse Polije.

3. There is still no special marketing system for poultry slaughterhouse Polije products.

4. Not yet focused on production(profit oriented)

5. Do not have a special means of transportation Poultry Slaughterhouse products

6. There is no standardized waste treatment of poultry slaughterhouse Polije

7. Do not have a special storage area(freezer)Poultry Slaughterhouse products

8. We don't have a strong marketing network yet.

The identification internal environment result that depicts strength and weakness is showed on Table 1 .

\subsection{External strategy factors matrix}

External environment analysis depicts opportunity and threat that owned by Tefa Polije. External environment analysis that depicts opportunity as follow.:

1. Product diversification can be applied if the market wants (chicken ungkep or the like)

2. Network marketing and a large target market (minimum Polije employees)

3. It is necessary to hold an exhibition of Polije's superior products to the wider community

4. Special discounts to Polije customers and employees

5. Can provide poultry cutting services at competitive prices

6. The potential increase in chicken consumption in Jember is still high.

7. Marketing system in the form of practical packaging is not much 
8. Fresh chicken products with digital marketing are not much business by increasing the business scale, increasing the types of products and services. Business expansion can

Table 1. Matrix IFAS Strategic Factors Strengths and Weaknesses

\begin{tabular}{|c|c|c|c|c|}
\hline No. & Strategic Factors of Strength(Strengths) & Weight & Score & Value \\
\hline 1 & Have a certified halal slaughterman & 4 & 0.07 & 0.27 \\
\hline 2 & Equipment for Poultry Slaughterhouse operational needs that are sufficient enough & 3 & 0.07 & 0.23 \\
\hline 3 & Has adequate facilities / sesuai standard minimall poultry slaughterhouse & 3 & 0.07 & 0.24 \\
\hline 4 & The location of poultry slaughterhouse Polije is quite strategic (in the city area) & 3 & 0.07 & 0.24 \\
\hline 5 & $\begin{array}{l}\text { Poultry carcass products produced are guaranteed to meet the criteria of ASUH (Safe, } \\
\text { Healthy, Whole, and Halal) }\end{array}$ & 4 & 0.08 & 0.28 \\
\hline 6 & Large enough target market (minimum Polije employees) & 3 & 0.07 & 0.24 \\
\hline 7 & $\begin{array}{l}\text { Has a marketing partner, namely The Polije Employee Cooperative which is strategically } \\
\text { located }\end{array}$ & 3 & 0.06 & 0.19 \\
\hline 8 & Has a good name (reputation) Polije as one of the best polytechnics in Indonesia & 4 & 0.07 & 0.27 \\
\hline \multicolumn{5}{|c|}{ Strategic Weaknesses(Weaknesses) } \\
\hline 1 & Production capacity has not been maximal and still needs to be increased. & 2 & 0.05 & 0.12 \\
\hline 2 & $\begin{array}{l}\text { There is no human resources (HR) and/or a dedicated professional team focused on } \\
\text { managing the production of poultry slaughterhouse Polije. }\end{array}$ & 3 & 0.05 & 0.14 \\
\hline 3 & There is still no special marketing system for poultry slaughterhouse Polije products. & 3 & 0.05 & 0.14 \\
\hline 4 & Not yet focused on production (profit oriented) & 3 & 0.05 & 0.13 \\
\hline 5 & Do not have a special means of transportation Poultry Slaughterhouse products & 3 & 0.05 & 0.13 \\
\hline 6 & There is no standardized waste treatment of poultry slaughterhouse Polije & 3 & 0.06 & 0.18 \\
\hline 7 & Do not have a special storage area (freezer) Poultry Slaughterhouse products & 3 & 0.06 & 0.16 \\
\hline 8 & We don't have a strong marketing network yet. & 3 & 0.05 & 0.14 \\
\hline \multicolumn{3}{|c|}{ Total } & $\mathbf{1 . 0 0}$ & 3.09 \\
\hline
\end{tabular}

While Internal environment analysis that depicts threat as follow:

1. There are already competitors with similar products (chicken carcass) around the location of poultry slaughterhouse Polije

2. Disposal of untreated poultry slaughterhouse waste has the potential to cause environmental pollution and social conflicts

3. Does not yet have a permanent supplier to supply the needs of poultry slaughterhouse Polije

4. Frozen food products based on poultry processed, especially chickens from large companies began to vary at competitive prices.

5. There is a strong poultry product marketing network(settle)

6. People's appetite for chicken products is increasingly practical.

7. Product prices are very competitive

8. People want digital purchases.

The identification external environment result that depicts opportunity and threat is showed on Tabel 2 .

Based on the results of the IFAS and EFAS matrix calculations, the total score for IFAS is 3.09 and EFAS is 2.97. So from the value above, it can be seen that the position of the strategy matrix for Tefa poultry slaughterhouse Polije is in the coordinates located in quadrant I, which means occupying the aggressive strategy. This shows that the position of poultry slaughterhouse Polije is very strong and supports the strategy to improve and develop the products produced. be done by developing marketing in different places and close to the market share so that it can overcome the weaknesses of the poultry slaughterhouse business, namely not having branches elsewhere.

Furthermore, it can be continued with the Concentric Diversification Strategy, namely Tefa poultry slaughterhouse Polije can add to the variety of products offered in order to attract consumer interest and Joint Ventures or joint ventures provide new opportunities with shareable risks, for example by collaborating with large companies in the marketing process so that Tefa can develop in the future. So with an increase in business scale, adding product variations, and collaborating with large companies, the Tefa Polije poultry slaughterhouse business will be able to develop and will progress so as to increase its profits.

\subsection{SWOT Strategy Matrix Analysis}

After analyzing the company's internal and external factors, then the next step is the preparation of several alternative strategies based on the SWOT analysis. The SWOT matrix can produce 4 alternative strategies, namely SO strategy (strength-opportunity), ST strategy (strength-threat), WO strategy (weakness-opportunity), WT strategy (weakness-threat) (Table 3).

Aggressive strategy is an activity to expand the 
Table 2. Matrix EFAS Strategic Factor of Opportunity and Threat

\begin{tabular}{|c|c|c|c|c|}
\hline No. & Strategic Factors ofOpportunity (Opportunity) & Weight & Score & Value \\
\hline 1 & $\begin{array}{l}\text { Product diversification can be applied if the market wants (fried chicken } \\
\text { ungkep or the like) }\end{array}$ & 3 & 0.07 & 0.25 \\
\hline 2 & $\begin{array}{l}\text { Anetwork of marketing and a large target market (minimum Polije } \\
\text { employees) }\end{array}$ & 3 & 0.07 & 0.25 \\
\hline 3 & $\begin{array}{l}\text { It is necessary to hold an exhibition of Polije's superior products to the wider } \\
\text { community }\end{array}$ & 3 & 0.07 & 0.23 \\
\hline 4 & Special discounts to Polije customers and employees & 3 & 0.07 & 0.23 \\
\hline 5 & Can provide poultry cutting services at competitive prices & 3 & 0.07 & 0.24 \\
\hline 6 & The potential increase in chicken consumption in Jember is still high. & 3 & 0.07 & 0.22 \\
\hline 7 & Stemmarketing in the form of packaging that practically not much & 3 & 0.07 & 0.26 \\
\hline 8 & Freshchicken with digital marketing is not much & 4 & 0.08 & 0.27 \\
\hline \multicolumn{5}{|c|}{ Strategic Threat Factors(Threats) } \\
\hline 1 & $\begin{array}{l}\text { There are already competitors with similar products (chicken carcass) around } \\
\text { the location of poultry slaughterhouse Polije }\end{array}$ & 2 & 0.05 & 0.12 \\
\hline 2 & $\begin{array}{l}\text { Disposal of untreated poultry slaughterhouse waste has the potential to cause } \\
\text { environmental pollution and social conflicts }\end{array}$ & 3 & 0.06 & 0.17 \\
\hline 3 & $\begin{array}{l}\text { Does not yet have a permanent supplier to supply the needs of poultry } \\
\text { slaughterhouse Polije }\end{array}$ & 2 & 0.05 & 0.11 \\
\hline 4 & $\begin{array}{l}\text { Frozen food products based on poultry processed, especially chickens from } \\
\text { large companies began to vary at competitive prices. }\end{array}$ & 3 & 0.06 & 0.15 \\
\hline 5 & There is a strong poultry product marketing network(settle) & 3 & 0.05 & 0.14 \\
\hline 6 & People's appetite for chicken products is increasingly practical. & 2 & 0.05 & 0.11 \\
\hline 7 & Product prices are very competitive & 2 & 0.05 & 0.11 \\
\hline 8 & Thepublic wants digital purchases & 2 & 0.05 & 0.11 \\
\hline \multicolumn{3}{|c|}{ Total } & 1.00 & 2.97 \\
\hline
\end{tabular}

Based on the results of the SWOT matrix above, several strategies can be obtained by poultry slaughterhouse business development in carrying out its marketing activities. The SWOT matrix above produces four strategies which include:

\subsubsection{S-O (strength-opportunity) strategy}

SO strategy is a strategy that uses strengths to take advantage of existing opportunities. The strategy that can be done to take the existing opportunities is to increase the availability of chicken supply due to the increasing number of people who consume chicken meat. In this case, it is necessary to increase the marketing network in the Jember area or outside the city of Jember, such as Lumajang, Situbondo, and Bondowoso.

\subsubsection{W-O Strategy (weakness-opportunities)}

The WO strategy is to overcome weaknesses by taking advantage of existing opportunities. The strategy that can be used is to increase production capacity by increasing business scale because the prospect of poultry slaughterhouse business development is quite promising and secondly by optimizing poultry slaughterhouse equipment to make it more efficient.

\subsubsection{ST strategy (strength-threat)}

ST strategy is to reduce the impact of threats by using existing strengths. The strategy that can be used is to develop a strategy to compete in the poultry slaughterhouse business because considering the increasing number of competitors who are also developing traditional poultry slaughterhouse businesses. Furthermore, poultry slaughterhouse can optimize tools and scale for supply preparation due to high demand during religious holidays.

\subsubsection{W-T Strategy (weakness-threats)}

WT strategy is to minimize weaknesses and face threats. The strategy that can be done is to continuously improve the quality of poultry slaughterhouse products in order to compete with traditional poultry slaughterhouse businesses. Second, it is necessary to be careful in opening new marketing and the need to implement digital marketing management such as e-commerce and social media. 
Table 3. SWOT matrix strategy diagram results

\begin{tabular}{|c|c|c|}
\hline Factor Eksternal & $\begin{array}{l}\text { Strength(S) } \\
\text { 1. Have a certified halal slaughterman } \\
\text { 2. Equipment for Poultry slaughterhouse } \\
\text { operational needs that are sufficient enough } \\
\text { 3.Has adequate facilities / as standard as mini } \\
\text { poultry slaughterhouse } \\
\text { 4. The location of poultry slaughterhouse } \\
\text { Polije is quite strategic (in the city area) } \\
\text { 5. Poultry Carcass products produced are } \\
\text { guaranteed to meet the criteria of ASUH (Safe, } \\
\text { Healthy, Whole, and Halal) } \\
\text { 6.A fairly large target market (minimum Polije } \\
\text { employees) } \\
\text { 7.Has a marketing partner, namely The } \\
\text { Politeknik Negeri Jember Employee } \\
\text { Cooperative which is strategically located } \\
\text { Has a good name (reputation) POLIJE as one } \\
\text { of the best polytechnics in Indonesia }\end{array}$ & $\begin{array}{l}\text { Weakness (W) } \\
\text { 1. Production capacity has not been } \\
\text { maximal and still needs to be increased. } \\
\text { There is no human resources (HR) and/or } \\
\text { a dedicated professional team focused on } \\
\text { managing the production of poultry } \\
\text { slaughterhouse Polije. } \\
\text { 3. There is still no special marketing } \\
\text { system for poultry slaughterhouse Polije } \\
\text { products. } \\
\text { 4. Not yet focused on production (profit } \\
\text { oriented) } \\
\text { 5.. Do not have a special means of } \\
\text { transportation Poultry slaughterhouse } \\
\text { products } \\
6 . \text { There is no standardized waste } \\
\text { treatment of poultry slaughterhouse } \\
\text { Polije }\end{array}$ \\
\hline $\begin{array}{l}\text { Opportunity (O) } \\
\text { Product diversification can be } \\
\text { applied if the market wants (fried } \\
\text { chicken ungkep or the like) } \\
\text { 2. Network marketing and target } \\
\text { market is quite large (minimum Polije } \\
\text { employees) } \\
\text { 3. It is necessary to hold an exhibition } \\
\text { of Polije superior products to the } \\
\text { wider community } \\
\text { 4. Special discounts to Polije } \\
\text { customers and employees } \\
\text { 5. Can provide poultry cutting } \\
\text { services at competitive prices } \\
\text { The potential for increased chicken } \\
\text { consumption in Jember is still high } \\
\text { 7. Marketing system in the form of } \\
\text { practical packaging is not much } \\
\text { 8. Fresh chicken products with digital } \\
\text { marketing are not much }\end{array}$ & $\begin{array}{l}\text { Strategies S-O } \\
\text { a. Maintaining and improving network } \\
\text { marketing } \\
\text { b.Member the availability of chicken due } \\
\text { to the increasing number of people } \\
\text { consuming chicken meat } \\
\text { c. A large enough target market then needs } \\
\text { a broad and strong marketing network } \\
\text { d. Poultry Carcass Products with } \\
\text { Diversification of fresh chicken products } \\
\text { sold with promotional and discount } \\
\text { models for customers and employees } \\
\text { e.Has a marketing partner, namely } \\
\text { Politeknik Negeri Jember Employee } \\
\text { Cooperative with digital marketing } \\
\text { f.Good name (reputation) Polije has the } \\
\text { potential to provide poultry slaughter } \\
\text { services }\end{array}$ & $\begin{array}{l}\text { Strategies W-O } \\
\text { a. Increased broiler cutting capacity } \\
\text { to diversify products } \\
\text { b. Create a digital marketing system } \\
\text { to reduce the buildup in the } \\
\text { product } \\
\text { c. The distribution of chicken } \\
\text { products with packaging } \\
\text { systems facilitates in marketing } \\
\text { transportation } \\
\text { d.Cutting services can be the focus } \\
\text { of Poultry slaughterhouse } \\
\text { business profit } \\
\text { e.Sewage treatment must be prepared } \\
\text { immediately in anticipation of } \\
\text { pollution }\end{array}$ \\
\hline $\begin{array}{l}\text { Threat } \\
\text { 1. There are already competitors with } \\
\text { similar products (chicken carcass) } \\
\text { around the location of poultry } \\
\text { slaughterhouse Polije } \\
\text { 2. Disposal of untreated poultry } \\
\text { slaughterhouse waste has the } \\
\text { potential to cause environmental } \\
\text { pollution and social conflicts } \\
\text { 3. Does not yet have a permanent } \\
\text { supplier to supply the needs of } \\
\text { poultry slaughterhouse Polije } \\
\text { 4. Frozen food products based on } \\
\text { poultry processed, especially } \\
\text { chickens from large companies began } \\
\text { to vary at competitive prices. } \\
\text { 5. There is a strong poultry product } \\
\text { marketing network (settle) } \\
\text { 6. People's appetite for chicken } \\
\text { products is increasingly practical. } \\
\text { 7. Product prices are very } \\
\text { competitive } \\
\text { 8. People want digital purchases. }\end{array}$ & $\begin{array}{l}\text { Strategies S-T } \\
\text { a. Develop strategies to compete in similar } \\
\text { businesses by optimizing existing } \\
\text { equipment and facilities } \\
\text { b. Develop a marketing model with frozen } \\
\text { food products } \\
\text { c. Carcass products that are guaranteed } \\
\text { quality can be the taste of the } \\
\text { community } \\
\text { d. Create a network of broiler chicken } \\
\text { suppliers live at competitive } \\
\text { prices to produce products that are } \\
\text { cheap and according to people's } \\
\text { tastes }\end{array}$ & $\begin{array}{l}\text { Strategies W-T } \\
\text { a. Apply continuous quality } \\
\text { improvements in order to } \\
\text { compete with other poultry } \\
\text { slaughterhouses } \\
\text { b. In maintaining the quality of the } \\
\text { product must be considered. } \\
\text { c. Not yet focused on production } \\
\text { (profit oriented) to find } \\
\text { customers of Tefa poultry } \\
\text { slaughterhouse Polije products } \\
\text { d.No storage space has been } \\
\text { immediately marketed } \\
\text { products at competitive prices. }\end{array}$ \\
\hline
\end{tabular}




\section{CONCLUSION}

The research concluded that the poultry slaughterhouse in Polije can be used as a teaching factory with wider development and higher production in producing carcasses marketed in Jember, because the position value of the strategy matrix for Tefa poultry slaughterhouse Polije is in the coordinates of quadrant I, which means it occupies on an aggressive strategy. This shows that the position of the Poultry slaughterhouse is very strong and supports the strategy to improve and develop the products produced.

\section{ACKNOWLEDGMENT}

The authors would like to thank P3M for funding the research conducted through the 2021 PNBP funding source with contract number 404 /PL17.4/PG/2021.

\section{REFERENCES}

[1] F. Tamalluddin, Panduan Lengkap Ayam Broiler, Jakarta (ID): Penebar Swadaya, 2016

[2] Standar Nasional Indonesia (SNI), Rumah Potong Unggas. SNI 01-6160-1999, Badan Standarisasi Nasional (BSN), Jakarta, 1999

[3] B. A. Murtidjo, Pemotongan dan Penanganan Daging Ayam, Yogyakarta (ID): Kanisius, 2003.

[4] Achmanu dan Muharlien, Ilmu Ternak Unggas, Malang (ID): UB Press, 2011.

[5] N., Fajaryati, Evaluasi pelaksanaan teaching factory SMK di Surakarta, Jurnal Pendidikan Vokasi, 2(3): 325-337, 2012.

[6] M. Nurtanto, S.D. Ramdani, S. Nurhaji, Pengembangan model teaching factory di sekolah kejuruan. Prosiding Seminar Nasional Pendidikan FKIP UNTIRTA dengan Tema "Pendidikan Sosial, Sains, dan Kejuruan yang Bermutu, Berkarakter, dan Berdaya Saing”. 6 Mei 2017, Banten. Hlm: 447-454, 2017.

[7] Direktorat Pembinaan Sekolah Menengah Kejuruan, Model Pengelolaan Teaching Factory. Direktorat Pembinaan Sekolah Menengah Kejuruan, Direktorat Jenderal Pendidikan Dasar dan Menengah, Kementrian Pendidikan dan Kebudayaan, 2019. 